\title{
LEMBAGA KONSERVASI SATWA DALAM PERSPEKTIF PERDAGANGAN SATWA ILEGAL ${ }^{1}$
}

\author{
Oleh : \\ I Gusti Ayu Pradnya Swari Dewi
}

\begin{abstract}
Indonesia is a country that is very rich its animal diversity, but is also know as a countrythat has a long list of endangered wildlife. The destruction of forests, the transfer function of over-harvesting and the destruction of their habitat is the main factor that threatens the extinction of wildlife. Forests as house a wide variety of wildlife is no longer able to protect the exixtence of wildlife due to habitat destruction. Various rare species endemic in Indonesia such as Sumateran tigers, one-horned rhino, the Javan hawk eagle, dragons, birds of paradise and other animals gravely threatened. Illegal wildlife trade proses a serious threat to the preservation of the wildlife. The wildlife illegally traded most are cought from the wild and not of capativity. By law the government efforts to protect endangered species from extinction is done with the issuance of Law No. 5 of 1990 on Conservation of Natural Resources and ecosystems followedby the enactment of Minister of Forestry Number : P.53/Menhut-II/2006 on Conservation. Public education to raise public awareness of the importance of wildlife conservation play an important role in wildlife conservation. Institutions ex-situ conservation becomes a toggle while during their forests in the rescue effort should be able to give life maximum for wildlife with regard to ethics and the rules of animal welfare so that the function and purpose of conservation agencies as a place of education, research and development of science can be fixed accomplished.
\end{abstract}

Keywords : Illegal Wildlife Trade, Conservation, Wildlife

\begin{abstract}
Abstrak
Indonesia merupakan negara yang sangat kaya dengan keanekaragaman satwanya, namun dikenal juga sebagai negara yang memiliki daftar panjang tentang satwa liar yang terancam punah. Perusakan hutan, pengalihan fungsi hutan yang berlebihan serta rusaknya habitat mereka merupakan faktor utama yang mengancam punahnya satwa liar tersebut. Hutan sebagai rumah berbagai macam satwa liar tidak lagi mampu melindungi keberadaan satwa akibat perusakan habitatnya. Berbagai satwa endemik yang langka di Indonesia seperti harimau Sumatera, badak bercula satu, elang jawa, komodo, burung cendrawasih dan satwa-satwa lainnya keberadaannya terancam punah. Secara hukum upaya pemerintah dalam melindungi satwa langka dari ancaman kepunahan dilakukan dengan dikeluarkannya Undang-Undang Nomor 5 Tahun 1990 tentang Konservasi Sumber Daya Alam Hayati dan Ekosistemnya selanjutnya diikuti

Karya Ilmiah Mahasiswa pada Program Studi Magister (S2) Ilmu Hukum Program Pascasarjana Universitas Udayana, Mengucapkan Terimakasih kepada Dr. Putu Tuni Cakabawa Landra, SH.,M. Hum dan Dr. I Ketut Westra, SH.,MH selaku Pembimbing Tesis

2 Mahasiswa Magister Hukum Universitas Udayana, Denpasar, Bali. e-mail : pradnya_indy@yahoo. co.id
\end{abstract}


dengan ditetapkannya Peraturan Mentri Kehutanan Nomor : P.53/Menhut-II/2006 tentang Lembaga Konservasi. Edukasi kepada masyarakat untuk meningkatkan kesadaran publik akan pentingnya pelestarian satwa liar memainkan peranan penting dalam pelestarian satwa liar.

Lembaga konservasi ex-situ menjadi tempat tiggal sementara selama hutan mereka dalam upaya penyelamatan harus mampu memberikan kehidupan yang maksimal bagi satwa liar tersebut dengan tetap memperhatikan etika dan kaidah kesejahteraan satwa sehingga fungsi dan tujuan lembaga konservasi sebagai tempat pendidikan, penelitian dan pengembangan ilmu pengetahuan dapat tetap terlaksana.

Keywords: Perdagangan Satwa Ilegal, Lembaga Konservasi, Satwa Liar

\section{PENDAHULUAN}

\subsection{Latar Belakang}

Indonesia sebagai negara

kepulauan yang terletak diantara dua

benua memiliki keanekaragaman hayati dengan tingkat kekhasan yang tinggi, membuat Indonesia memiliki peran yang sangat penting dalam perdagangan satwa dunia. Sebagai Negara yang menyimpan banyak keanekaragaman jenis satwa liar dan merupakan salah satu Negara yang memiliki tingkat keterancaman terhadap kepunahan satwa liar, kondisi ini tentu sangat mengkhawatirkan secara nasional maupun global. Hal ini dapat dilihat dari sulitnya untuk melihat beberapa jenis satwa liar di habitat aslinya, seperti badak bercula satu, burung cendrawasih, anoa, gajah Sumatera, harimau Sumatera dan masih banyak lagi satwa-satwa lainnya yang terancam punah.

Ancaman penurunan populasi dan kepunahan satwa yang dilindungi terus berlangsung. Perubahan area hutan menjadi perkebunan sawit, pertambangan dan tanaman industry menjadi ancaman yang sangat serius bagi kelestarian satwa liar, termasuk satwa langka. Perburuan satwa liar yang terus berlangsung seiring dengan pembukaan hutan alami membuat habitat satwa semakin menyusut. Semakin meningkatnya jumlah penduduk dan pembangunan ekonomi juga membawa akibat yang serius terhadap penciutan habitat satwa. Keadaan ini telah membawa konsekuensi buruk terhadap pertumbuhan populasi satwa, terutama karena mereka terkurung dalam habitatnya yang menjadi sempit. Pergerakannya akan berbenturan dengan kegiatan manusia, akibatnya banyak terjadi konflik dengan manusia.

Konflik yang sangat nyata terjadi antara manusia dengan harimau, gajah dan orangutan. Di Pulau Sumatera, konflikgajahataupun harimau, semakin meningkat dan telah menimbulkan banyak korban baik manusia yang tewas maupun harimau dan gajah yang terbunuh. Demikian juga di Pulau Kalimantan konflik antara manusia dengan orangutan sudah mulai 
terjadi. Pembabatan, pembakaran, dan kebakaran hutan telah memusnahkan spesies-spesies satwa serta merusak unsur hara tanah. Aktivitas lain berupa penyemprotan hama dan obat pembasmi pestisida dan sejenisnya yang sukar terurai akan merembes ke dalam rantai-rantai makanan, yang selanjutnya akan berpengaruh kepada mahluk-mahluk lain.

Setelah masalah habitat yang semakin menyusut secara kualitas dan kuanitas, perdagangan satwa justru menjadi ancaman serius. Tingginya tingkat perburuan dan perdagangan liar yang disebabkan karena tingginya permintaan pasar terhadap jenis-jenis satwa liar, ditambah penawaran harga yang tinggiuntukjenis-jenis satwayang sangat langka, semakin mengancam keberadaan satwa-satwa liar tersebut. Satwa yang merupakan hasil tangkapan dari alam diperdagangkan secara bebas. Sebagian masyarakat gemar memperjualbelikan satwa dilindungi dalam keadaan hidup untuk dipelihara, untuk dimanfaatkan organ tubuh satwa sebagai bahan obat tradisional, maupun dalam bentuk hewan yang sudah diawetkan.

Perdagangan ilegal satwa liar berlangsung terus-menerus dan berkembang dengan sangat pesat. Perdagangan ini bersifat sangat kompleks dan melibatkan banyak pihak mulai dari pemburu, eksportir bahkan tidak sedikit kasus perdagangan ilegal satwa liar yang melibatkan oknum petugas serta aparat keamanan. Perdagangan ilegal juga merupakan kejahatan yang telah terorganisir dengan rapi, memiliki jaringan yang kuat serta dengan modus penyelundupan yang terus berkembang.

Satwa-satwa liar yang biasanya diperjualbelikan ini kebanyakan adalah satwa langka dari jenis burungburungan (aves) sepertu kakatua raja, kakatua jambul kuning, gelatik, burung bayan maupun jenis mamalia atau primata seperti monyet hitam atau jenis-jenis lainnya yang kebanyakan dipelihara manusia sebagai unsur kesenangan saja. Satwa-satwa tersebut diburu dari alam kemudian diselundupkan untuk kemudian diperdagangkan diberbagai kota besar bahkan hingga mancanegara.

Indonesia termasuk Negara yang memberikan kontribusi cukup besar dalam perdagangan organ satwa liar diperuntukkan untuk memasok perdagangan obat tradisional, makanan khas, dan aksesoris (termasuk bulu/ kulit binatang). Bahkan perkembangan terbaru dari perdagangan satwa langka ini adalah dilakukan denggan menggunakan media jejaring sosial internet. Perdagangan satwa langka yang selama ini berlangsung tertutup dan ilegal, kini menjadi lebih mudah dan terbuka. Melalui jejaring sosial, pemilik satwa langka justru dengan terang-terangan mempromosikannya dengan memasang foto satwa yang diperdagangkannya.

Satwa liar yang diperdagangkan tersebut sebagian besar merupakan hasil tangkapan dari alam bukan dari 
penangkaran. Penangkapan yang tidak ramah lingkungan terhadap satwa liar menimbulkan kerusakan ekosistem yang apabila terus dibiarkan, maka dikhawatirkan suatu saat akan terjadi kepunahan yang menyebabkan generasi mendatang hanya akan bisa mengenal satwa-satwa tersebut melalui foto dokumentasi saja.

Selain ancaman yang diakibatkan oleh manusia, ancaman kepunahan keanekaragaman hayati terutama satwa liar juga sebagai akibat alamiah antara lain perubahan iklim global dan penyakit. Mengingat sifatnya yang tidak dapat digantikan, maka upaya konservasi menjadi kewajiban mutlak tiap generasi dan tanggung jawab pemerintah serta masyarakat.

\subsection{Perumusan Masalah}

1. Bagaimana peranan lembaga konservasi satwa dalam menjaga kelestarian satwa liar yang dilindungi ?

2. Bagaimana upaya perlindungan terhadap perdagangan ilegal satwa liar yang dilindungi ?

\subsection{Tujuan Penelitian}

Lembaga konservasi sebagai tempat pengembangbiakan dan penyelamatan satwa merupakan tempat tinggal sementara satwa dari kepunahan. Dalam hal ini yang menjadi obyek yang terkait mengenai pelestarian satwa liar yang dilindungi dari perdagangan ilegal.

Disamping tujuan umum tersebut diatas, penelitian ini secara spesifik diharapkan mampu :

1. Untuk mengetahui peranan lembaga konservasi satwa dalam menjaga kelestarian satwa liar yang dilindungi.

2. Untuk mengetahui upaya perlindungan terhadap perdagangan ilegal satwa liar yang dilindungi.

\section{METODE PENELITIAN}

Penelitian ini menggunakan metode penelitian hukum empiris, yaitu cara atau prosedur yang digunakan untuk memecahkan masalah penelitian dengan meneliti data skunder terlebih dahulu dan kemudian dilanjutkan dengan meneliti data primer yang ada di lapangan.

Sifat penelitian dalam karya ilmiah ini adalah deskriptif, yaitu bertujuan menggambarkan secara tepat sifat-sifat suatu individu atau kelompok tertentu, keadaan, gejala, atau untuk menentukan penyebaran suatu gejala, atau untuk menentukan ada tidaknya hubungan antara suatu gejala dengan gejala lain dalam masyarakat.

III. HASIL DAN PEMBAHASAN

3.1. Peranan Lembaga Konservasi Satwa Dalam Menjaga Kelestarian Satwa Liar Yang Dilindungi

Berkurangnya luas hutan menjadi ancaman penurunan dan kepunahan satwa liar di Indonesia. Penyebab utama kepunahan satwa liar diantaranya adalah kehilangan, keruskan serta fragmentasi habitat 
tempat hidup, pemanfaatan secara berlebihan dan perburuan serta perdagangan ilegal. Satwa liar dalam Pasal 1 Ayat 7 Undang-Undang Nomor 5 Tahun 1990 adalah :

Semua binatang yang hidup di darat, dan atau di air, dan atau di udara yang masih mempunyai sifat-sifat liar, baik yang hidup bebas maupun yang dipelihara oleh manusia.

Satwa liar dibagi menjadi 2 golongan yaitu jenis dilindungi dan jenis yang tidak dilindungi.

Pemanfaatan satwa liar secara langsung ada beberapa macam, antara lain :

1. Perburuan tradisional untuk makan yang biasa dilakukan oleh suku-suku pedalaman.

2. Perburuan tradisional seperti kulit yang biasanya digunakan sebagai bahan pembuat tas, baju/ hiasan lain oleh penduduk asli.

3. Mengumpulkan dan menjual jenis satwa liar

4. Menjual produk-produk dari satwa liar, seperti : daging, kulit, rahang, cula dan gading.

5. Berburu untuk tujuan memperoleh penghargaan atau untuk olahraga wisatawan.

6. Melindungi satwa liar di taman nasional sebagai atraksi untuk wisatawan yang harus membayar bila akan melihat, meneliti, memotret atau mendekatinya. ${ }^{3}$

Wiranto, dkk, 2001, Berkaca dicermin Retak: Refleksi Konservasi dan Implikasi Bagi Pengelolaan Taman Nasional, The Gibon Foundation, Jakarta, hlm. 106-107.
Perdagangan satwa liar secara ilegal menjadi ancaman serius bagi kelestarian satwa liar di Indonesia. Tingginya keuntungan yang dapat diperoleh dan kecilnya resiko hukum yang harus dihadapi oleh pelaku perdagangan ilegat tersebut membuat perdagangan satwa ilegal menjadi daya tarik besar bagi para pelaku untuk melakukan tindak kejahatan tersebut tanpa memperhatikan kelangsungan kelestarian satwa, bahkan mengganggu keseimbangan ekosistem dan siklus rantai makanan yang ada.

Perdagangan tumbuhan dan satwa liar di Indonesia sebagai bentuk pemanfaatan telah diatur dalam Peraturan Pemerintah Nomor 8 Tahun 1999 tentang Pemanfaatan Jenis Tumbuhan dan Satwa Liar dan ketentuan dalam CITES. Dalam peraturan tersebut dinyatakan bahwa tumbuhan dan satwa liar yang dapat diperdagangkan adalah jenis satwa liar yang tidak dilindung yang diperoleh dari hasil penangkaran maupun pengambilan atau penangkapan dari alam.

Ada beberapa hal yang melatarbelakangi maraknya kejahatan terhadap satwa liar di Indonesia, diantaranya :

1. Adanya permintaan pasar

2. Nilai ekonomi yang tinggi

3. Kondisi sosial ekonomi masyarakat

4. Penegakan hukum lemah

5. Isu belum menjadi permasalahan nasional. 
Memelihara hewan merupakan salah satu kegemaran/hobby manusia. Namun demikian sebagian orang memiliki kegemaran untuk memelihara jenis-jenis tertentu seperti memelihara burung kakak tua, primata dan sebagainya. Semakin langka satwa tersebut maka kepuasan seseorang akan kegenarannya tersebut semakin tinggi. Di dunia maya banyak sekali forum atau kumpulan orang-orang yang memiliki kegemaran yang sama yaitu memelihara satwa liar, seperti forum pencinta burung paruh bengkok, elang, burung hantu, dan sebagainya. Kegemaran inilah yang kemudian memicu maraknya perdagangan dan perburuan satwa liar terutama jenis-jenis langka. Berkaitan dengan kegemaran tersebut, sejumlah orang merasa status sosial atau gengsinya akan naik jika dapat mengkoleksi jenis satwa liar tersebut atau bagian tubuhnya.

Tingginya permintaan terhadap satwa liar juga dipicu berkembangnya mitosdimasyarakatjikamengkonsumsi bagian-bagian tertentu dari satwa liar dapat meningkatkan kekuatan, kewibawaan, dan sebagainya. Seperti misalnya dengan memiliki kumis harimau akan menambah kewibawaan, mengkonsumsi tangkur buaya akan menambah kekuatan, dan lain-lain. Mengkonsumsi bagian-bagian tertentu dari satwa liar juga diyakini sebagai bahan obat, terutama obat tradisional. Banyak jenis bagian tubuh satwa yang secara empiris digunakan dan dipercaya memiliki khasiat obat, misalnya empedu beruang madu yang dapat dijadikan sebagai obat untuk luka akibat patah tulang, terkilir dan kecelakaan ringan. Padahal beruang madu termasuk jenis yang dilindungi dan masuk dalam Apendiks I CITES. Selain masyarakat lokal, di beberapa tempat seperti China bayak sekali obat-obat tradisional yang berbahan dasar satwa dilindungi, seperti tulang harimau, sisik trenggiling, tanduk rusa, cula badak, dan sebagainya. Sehingga banyak kasus penyelundupan sisik trenggiling maupun tulang harimau yang berasal dari Indonesia dengan tujuan China.

$\begin{array}{lcr} & \text { Besarnya } & \text { keuntungan } \\ \text { nilai } & \text { ekonomi yang diperoleh } \\ \text { dari } & \text { perdagangan ilegal satwa }\end{array}$ liar dan kondisi sosial ekonomi masyarakat terutama sekitar hutan menyebabkan perburuan satwa terus berlangsung. Masyarakat yang kurang mengindahkan asas konservasi, mengambil satwa-satwa liar tersebut dari alam tanpa membudidayakan terlebih dahulu bahkan pengambilan sumberdaya alam itu tidak sebatas kebutuhan pengobatan semata, melainkan sebagai mata pencaharian. Pemanfaatan yang berlebihan tesebut menyebabkan kehidupan satwa liar akan berada diambang kepunahan apabila usaha perlindungan dan pelestariannya tidak segera dilakukan secara maksimal. Untuk menjamin kelestarian keberadaan satwa liar, perlu dilakukan tindakan konservasi berupa 
pengelolaan yang berkelanjutan yang menjamin terjadinya keseimbangan antara kegiatan perlindungan dan pemanfaatan sumber daya alam hayati. Peranan lembaga konservasi pun menjadi sangat penting. Kawasan konservasi di Indonesia ditunjuk dan ditetapkan oleh pemerintah berdasarkan krieria tertentu sesuai dengan peruntukannya. Aturan tentang kawasan konservasi di Indonesia dipayungi oleh UndangUndang Nomor 5 Tahun 1990 tentang Konservasi Keanekaragaman Sumber Daya Alam Hayati dan Ekosistemnya dan Peraturan Menteri Kehutanan No. P.53/Menhut-II/2006 tentang Lembaga Konservasi, yang dalam Pasal 1 ayat 3 menyebutkan bahwa :

Lembaga Konservasi adalah lembaga yang bergerak di bidang konservasi tumbuhan dan atau satwa liar diluar habitatnya (ex-situ) yang berfungsi untuk pengembangbiakan dan atau penyelamatan tumbuhan dan atau satwa dengan tetap menjaga kemurnian jenis guna menjamin kelestarian keberadaan dan pemanfaatannya.

Oleh karena satwa liar merupakan kekayaan alam yang perlu dijaga kelestariannya, upaya konservasi merupakan salah satu upaya untuk melestarikannya yang dapat dilakukan secara in-situ dan exsitu. ${ }^{4}$ Pelestarian in-situ merupakan usaha pelestarian yang dilakukan

Muhamad Erwin, SH., M.Hum., 2011, Hukum Lingkungan Dalam Sistem Kebijaksanaan Pembangunan Lingkungan Hidup, PT Refika Aditama, Bandung, hlm. 149. di habitat aslinya. Pelestarian ini ditekankan agar suatu jenis satwa di habitat aslinya tetap terjaga dan terpelihara yang dilakukan di tempattempat yang dilindungi pemerintah atau yang sering dipadankan dengan on spot. Konservasi ini mencakup kawasan suaka alam (Cagar Alam dan Suaka Margasatwa) dan kawasan pelestarian alam (Taman Nasional, Taman Hutan Raya, dan Taman Wisata Alam). Contohnya : pelestarian Badaj Jawa di Taman Nasional Ujung Kulon. Sedangkan pelestarian ex-situ adalah kegiatan konservasi diluar habitat aslinya, dimana fauna tersebut diambil, dipelihara pada suatu tempat tertentu dan dijaga keamanannya maupun kesesuaian ekologinya, atau yang sering dipadankan dengan out of spot.

Konservasi ex-situ ini dilakukan oleh lembaga konservasi, seperti kebun raya, arbetrum, kebun binatang, taman safari, dan tempat penyimpanan benih dan sperma satwa. ${ }^{5}$ Adapun tujuan dari perlindungan dan pelestarian ini tidak hanya untuk menyelamatkan satwa dari ancaman kepunahan, akan tetapi mengusahakan terjaminnya keanekaragaman hayati dan keseimbangan unsur-unsur ekosistem yang telah mengalami gangguan akibat meningkatnya aktivitas manusia yang merambah kawasan hutan alam.

Hak dan kewajiban lembaga konservasi pun diatur dalam Surat

Bambang Pamulardi, 1999, Hukum Kehutanan dan Pembangunan Bidang Kehutanan, PT Raja Grafindo Persada, Jakarta, hlm. 187. 
Keputusan Menteri Kehutanan dan Perkebunan Nomor 479/KptsII/1998 tentang Lembaga Konservasi Tumbuhan dan Satwa Liar, yang dalam Pasal 9 mencantumkan tentang kewajiban, antara lain : membuat rencana karya pengelolaan, menyediakan sarana dan prasarana pengelolaan, memelihara dan menangkarkan jenis tumbuhan dan satwa sesuai ketentuan yang berlaku, mempekerjakan tenaga ahli sesuai bidangnya, dilarang memperjual belikan satwa yang dilindungi dan membuat laporan pengelolaan secara berkala termasuk mutasi jenis satwa.

Lembaga konservasi yang mempunyai fungsi utama untuk pengembangbiakan dan atau penyelamatan tumbuhan dan satwa dan fungsi lainnya sebagai tempat pendidikan, peragaan, penelitian dan pengembangan ilmu pengetahuan, sarana perlindungan dan pelestarian jenis, serta sarana rekreasi yang sehat, dalam pengelolaannya tetap dilakukan berdasarkan etika dan kaidah kesejahteraan satwa (animal welfare).

Di dalam animal welfare atau kesejahteraan satwa dikenal 5 prinsip kebebasan (five freedoms principle), meliputi :

1. Bebas dari rasa lapar, haus dan kekurangan gizi (freedom from hunger and thirst).

2. Bebas dari rasa tidak nyaman secara fisik dan cuaca panas (freedom from discomfort).

3. Bebas dari rasa sakit, luka dan
Vol. 5, No. 2 : 406 - 419 http://ojs.unud.ac.id/index.php/jmhu

penyakit (freedom from pain, injury and disease).

4. Bebas mengekspresikan prilaku normal (freedom to express normal behavior).

5. Bebas dari rasa stress dan tertekan (freedom from fear and distress).

Kelima prinsip tersebut tidak dapat dilihat sebagai prinsip yang terpisah-pisah. Tidak terpenuhinya salahsatukebebasanakanmenyebabkan terganggunya kebebasan yang lain. Lembaga konservasi sebagai tempat tinggal sementara satwa liar dan tempat pengembangbiakan sertapenyelamatan satwa harus mampu berperan dalam menjaga kelestarian satwa liar yang dilindungi dari kepunahan.

Indonesia kini menjadi sorotan dunia internasional terkait dengan adanya kasus penangkapan penyelundupan satwa liar kakaktua jambul kuning yang dilakukan oleh petugas bea cukai di Tanjung Perak, Surabaya, Jawa Timur. Penyelundupan 21 ekor burung kakaktua jambul kuning dan burung bayan dilakukan dengan cara yang keji, yaitu dengan memasukkan burung tersebut ke dalam botol mineral. Selama tahun 2015 sudah terjadi 3 kasus penyelundupan kakaktua yang dilakukan dengan cara yang sama. Kakaktua jambul kuning mengalami ancaman kepunahan yang pada tahun 2007 hanya tersisa 7000 di dunia.

Kasus lainnya adalah kasus penyelundupan 14 ekor orang utan 
asal Indonesia yang direpatriasi dari Thailand akhirnya dipulangkan ke tanah air. Repatriasi orang utan ini adalah merupakan yang ketiga kalinya, yaitu pada tahun 2006 telah direpatriasi 48 orang utan dan pada tahun 2007 direpatriasi 4 orang utan. Kembalinya orang utan ini merupakan komitmen Pemerintah Indonesia dalam memerangi perdagangan satwa ilegal. Orang utan tersebut akan dipulangkan ke Kalimantan namun sebelumnya orang utan ini akan mengalami karantina di salah satu lembaga konservasi untuk memulihkan kesehatan maupun prilaku liarnya. Setelah pulih, orang utan tersebut akan dilepasliarkan kembali ke habitat alaminya sesuai dengan tes DNA (Deoxyribo Nucleic Acid).

Meskipun telah dilindungi di tingkat nasional dan internasional, perdagangan satwa liar dan langka masih terus terjadi. vonis ringan yang dijatuhkan ke penyelundup satwa semakinmenunjukkanbetapalemahnya penegakan hukum perlindungan satwa di Indonesia. Dalam hal ini, lembaga konservasi dalam peranannya menjaga kelestarian satwa melakukan beberapa langkah diantaranya :

1. Membuat penangkaran bagi satwa-satwa yang dilindungi.

2. Melakukan upaya pengembangbiakan dan perkawinan satwa-satwa langka untuk mengembangkan populasi satwa dan menghindari kepunahan satwa tersebut.
3. Melakukan penyelamatan dan pelepasliaran satwa kealam bebas agar bisa hidup secara alamiah.

4. Memberikan edukasi kepada masyarakat pentingnya kelestarian satwa untuk tetap hidup di habitatnya, sehingga mereka tidak lagi mengusik keberadaan satwa dan menjaga satwa-satwa tersebut untuk tetap hidup di habitat aslinya.

\subsection{Upaya Pencegahan Terhadap Perdagangan Satwa Ilegal}

Perdagangan satwa liar ilegal di Indonesia telah berkembang dan memberi kontribusi yang sangat besar pada punahnya satwa liar yang paling berharga. Maraknya perdagangan ilegal satwa yang dilindungi tidak hanya merupakan masalah pada tingkat lokal dan nasional saja, tapi bahkan sampai pada tingkat internasional. Hal ini dapat dilihat dari telah ditandatanganinya Convention on International Trade in Endangered Species (CITES) pada tahun 1973, yaitu sebuah perjanjian multilateral yang memberikan mekanisme internasional untuk mengatur perdagangan satwa liar.

Sampai saat ini terdapat 180 negara yang menjadi peserta CITES. Walaupun CITES bersifat mengikat secara hukum bagi negara yang ikut serta dalam konvensi ini, mengharuskan negara yang ikut serta untuk menerapkan peraturan domestik CITES untuk memastikan bahwa CITES diimple- 
mentasikan pada tingkat nasional. Pemerintah Indonesia meratifikasi CITES, dengan dikeluarkannya Keputusan Presiden Nomor 43 Tahun 1978 yang memuat daftar jenis-jenis satwa dan tumbuhan liar yang termasuk dalam kategori kelangkaan. Walaupun Indonesia menyetujui CITES pada tahun 1978, tapi undang-undang pelaksanaan nasional baru dilaksanakan pada tahun 1990 dengan diberlakukannya Undang-Undang Nomor 5 Tahun 1990 tentang Konservasi Sumber Daya Alam Hayati dan Ekosistemnya.

CITES mengatur dan mengawasi perdagangan dengan menetapkan tumbuhan dan satwa liar berdasarkan 3 (tiga) kategori perlakuan perlindungan dari eksploitasi perdagangan yaitu Appendix I adalah daftar di dalam CITES yang memuat jenis-jenis yang telah terancam punah (endangered) sehingga perdagangan internasional spesimen yang berasal dari habitat alam harus dikontrol dengan ketat dan hanya diperkenankan untuk kepentingan non-komersial tertentu dengan ijin khusus. Appendix II adalah daftar didalam CITES yang memuat jenis-jenis yang saat ini belum terancam punah, namun dapat menjadi terancam punah apabila perdagangan internasionalnya tidak dikendalikan. Appendix III adalah daftar didalam CITES yang memuat jenis-jenis yang oleh suatu Negara tertentu pemanfaatannya dikendalikan dengan ketat dan memerlukan bantuan pengendalian internasional. ${ }^{6}$

Muhamad Erwin, SH., M.Hum., Op.Cit, hlm. 184
Vol. 5, No. 2 : 406 - 419

http://ojs.unud.ac.id/index.php/jmhu
Majelis Umum Perserikatan Bangsa-Bangsa (PBB) pun telah menyerukan semua negara untuk meningkatkan upaya mengatasi perburuan dan perdagangan ilegal satwa liar. PBB mendesak negara-negara anggotanya untuk mengambil langkah tegas di tingkat nasional untuk mencegah, memerangi dan memberantas perdagangan satwa illegal dari sisi pasokan maupun permintaan. Dalam Pasal 21 ayat 2 huruf a Undang-Undang Nomor 5 Tahun 1990 menyebutkan bahwa : setiap orang dilarang untuk menangkap, melukai, membunuh, menyimpan, memiliki, memelihara, mengangkut, dan memperniagakan satwa yang dilindungi dengan keadaan hidup.

Ketentuan ini mencerminkan bahwa ketentuan hukum terkait dengan perdagangan satwa liar yang dilindungi berikut larangan dan sanksi yang dikenakan kepada para pelakunya sebenarnya telah disediakan.

Upaya perlindungan terhadap satwa liar dan penegakan hukum perburuan dan peredaran ilegal satwa liar perlu terus dilakukan. Pada tingkat Asia Tenggara, pemerintah juga telah melakukan kerjasama dalam ASEAN Wildlife Enforcement Network (ASEAN-WEN) yang dibentuk pada pertemuan Menteri-Menteri negara ASEAN yang bertanggungjawab dalam implementasi CITES di Bangkok tanggal 1 Desember 2005. Tujuan pembentukan ASEAN-WEN adalah 
untuk meningkatkan hubungan aparat penegak hukum antar negara ASEAN dalam memberantas perdagangan satwa liar.

Perdagangan jenis satwa liar harus diawali dengan penetapan kuota pengambilan atau penangkapan satwa liar dari alam yang merupakan batas maksimal jenis dan jumlah spesimen satwa liar yang dapat diambil dari habitat alam yang didasarkan pada prinsip kehati-hatian untuk mencegah terjadinya kerusakan atau degradasi populasi. Penetapan kuota pengambilan dan penangkapan satwa liar dilakukan oleh Direktur Jendral PHKA berdasarkan rekomendasi LIPI. Penyusunan kuota didasari bahwa ketersediaan data potensi satwa liar yang menggambarkan populasi dan penyebaran setiap jenis masih sangat terbatas, sehingga membutuhkan peran LSM (Lembaga Swadaya Masyarakat) dan Perguruan Tinggi untuk memberikan informasi mengenai potensi dan penyebaran jenis satwa liar yang dapat dimanfaatkan.

Perijinan dan penangkapan satwa liar diterbitkan oleh BKSDA (Balai Konservasi Sumber Daya Alam) berdasarkan kuota wilayah yang ada. Perijinan badan usaha atau perorangan yang akan melakukan peredaran satwa liar di dalam negeri diterbitkan oleh kepala BKSDA dimana badan usaha atau perorangan yang memegang ijin sebagai pengedar satwa dalam negeri yang akan mengambil atau menangkap satwa berkewajiban untuk mempun- yai tempat dan fasilitas penampungan satwa liar yang memenuhi syarat yang telah ditetapkan oleh Dirjen PHKA. Sedangkan peredaran satwa liar ke luar negeri harus sesuai ijin BKSDA dan sesuai dengan syarat-syarat yang ditetapkan CITES.

Pencegahan terhadap perdagangan ilegal satwa liar yang dilindungi di Indonesia terus dilakukan. Undang-Undang Nomor 5 Tahun 1990 tentang Konservasi Sumber Daya Alam Hayati dan Ekosistemnya dengan ancaman denda maksimum Rp. 100.000.000,- (seratus juga rupiah) dan pidana penjara 5 (lima) tahun dianggap sudah tidak efektif dan belum memberikan vonis maksimal sehingga tidak membuat pelaku menjadi takut, tapi justru satwa tersebut makin marak diperjual-belikan bahkan ada tempat khusus memperjual-belikan satwa yang dilindungi tersebut. Lemahnya penegakan hukum dan besarnya keinginan untuk memelihara dan memiliki satwa demi kesenangan, memicu semakin maraknya kepemilikan satwa langka secara ilegal.

Menurut Rosen and Smith (2010) kondisi saat ini perdagangan ilegal tumbuhan dan satwa liar sangat membahayakan, perlu lebih banyak sumber daya yang harus ditujukan untuk menyelidiki dan mengatur perdagangan ilegal tumbuhan dan satwa liar pada level lokal, regional dan internasional. Pada tingkat lokal kampanye dan edukasi untuk masyarakat tentang perdagangan ilegal dan dampaknya 
dapat membantu untuk mengurangi permintaan.

Penegakan hukum yang dapat dilakukan ada 2 (dua) bentuk yaitu pencegahan (belum kejahatan terjadi) dan pengendalian/represif (setelah kejahatan terjadi). Dipelukan beberapa langkah agar perdagangan satwa liar tersebut bisa diselesaikan, misalnya dengan melakukan monitoring perburuan dan perdagangan ilegal satwa, melakukan peningkatan kapasias aparat penegak hukum, khususnya yang terkait dengan peraturan perlindungan spesies dan pemahaman tentang ekologi satwa, peningkatan kerjasama antara Kementrian Kehutanan dengan aparat penegak hukum dan instansi terkait lainnya, peningkatan kerjasama di tingkat regional dan global, serta pemberdayaan masyarakat di sekitar hutan. Untuk melakukan pencegahan dan monitoring pemburuan dan perdagangan ilegal, diperlukan unit patrol, misalnya Tiger Patrol Unit, Rhino Patrol Unit, Orangutan Patrol Unit, dan lain sebagainya. Upaya dan dukungan dari pemerintah untuk melakukan pembaharuan undang-undang dan pemberian sanksi yang lebih berat kepada pelaku kejahatan terhadap satwa juga sangat diperlukan. Pemerintah ataupun aparatur penegak hukum tidak dapat bekerja sendiri dalam penanganan kasus perdagangan satwa liar tersebut. Kerjasama dengan lembaga swadaya masyarakat maupun lembaga pemerintah yang berkaitan dengan perlindungan satwa juga sangat diperlukan sebagai tempat
Vol. 5, No. 2 : 406 - 419

http://ojs.unud.ac.id/index.php/jmhu

rehabilitasi satwa hasil operasi yang dilakukan oleh pemerintah dari kasus perdagangan liar. Kesadaran masyarakat tentang bahaya perdagangan ilegal satwa liar dengan tidak membeli dan memelihara satwa liar akan membatu untuk memberhentikan perdagangan satwa liar tersebut.

\section{PENUTUP}

\subsection{Simpulan}

1. Lembaga konservasi satwa mempunyai peranan yang sangat penting untuk menjaga kelestarian satwa liar yang dilindungi sesuai dengan tujuan dan fungsi Lembaga Konservasi serta mencegah adanya perdagangan ilegal satwa yang dilindungi ntuk mencegah adanya kepunahan satwa-satwa dilindungi.

2. Upaya-upaya yang dilakukan dalam mencegah perdagangan satwa yang dilindungi yaitu dengan upaya preventif/ pencegahan yaitu dengan cara melakukan penangkaran satwa, pengembangbiakan, serta pelepasliaran. Sedangkan upaya represif/pengendalian yaitu dengan melakukan peningkatan pengawasan dan penegakan sanksi terhadap perdagangan ilegal satwa yang dilindungi.

\subsection{Saran}

1. Pemerintah dengan lembagalembaga terkait dengan 
perlindungan satwa liar hendaknya memiliki komitmen yang tinggi dalam melakukan pengawasan dan pencegahan terhadap perdagangan ilegal satwa liar yang dilindungi baik dengan cara memformulasikan kembali sanksi yang lebih tegas dan penindakan yang lebih tegas terhadap pelanggaran undangundang perlindungan satwa untuk menghindari kepunahan satwa liar yang dilindungi.

2. Lembaga konservasi satwa hendaknya lebih mengutamakan fungsiperlindungansatwadengan melakukan kerjasama dengan organisasi kemasyarakatan atau LSM serta meningkatkan pemahaman anggota masyarakat akan pentingnya perlindungan dan pelestarian terhadap satwa liar yang dilindungi.

\section{DAFTAR PUSTAKA}

\section{Buku}

Bambang Pamulardi, 1999, Hukum Kehutanan dan Pembangunan Bidang Kehutanan, PT Raja Grafindo Persada, Jakarta.

Chefid Fandeli, 2009, Prinsip-Prinsip Dasar Mengkonservasi Lanskap, Gadjah Mada University Press, Yogyakarta.

Chafid Fandeli, 2012, Bisnis Konservasi, Pendekatan Baru dalam Pengelolaan Sumberdaya Alam dan Lingkungan Hidup, Gadjah Mada University Press, Yogyakarta.
Hadi S. Alikondra, 2012, Konservasi

Sumberdaya Alam dan Lingkungan Pendekatan Ecosophy Bali Penyelamatan Bumi, Gadjah Mada University Press, Yogyakarta.

HR. Mulyanto, 2008, Efek Konservasi dari Sistem SABO Untuk Pengendalian Sedimentasi Waduk, Graha Ilmu, Yogyakarta.

Iskandar, 2015, Ilmu Kehutanan Prinsip Hukum Pelestarian Fungsi Lingkungan Hidup Dalam Kebijakan Pengelolaan Kawasan Hutan Berkelanjutan, CV Mandar Maju, Bandung.

Much. Taufik Tri Hermawan, Lies Rahayu Wijayanti Faida, Kristiani Fajar Wianti, Hero Marhaento, Amalia Anindia, 2014, Pengelolaan Kawasan Konservasi, Gadjah Mada University Press, Yogyakarta.

Muhamad Erwin, 2011, Hukum Lingkungan Dalam Sistem Kebijaksanaan Pembangunan Lingkungan Hidup, PT Refika Aditama, Bandung.

Susan Clayton, Gene Myers, 2014, Psikologi Konservasi, Pustaka Pelajar, Yogyakarta.

Wiranto, dkk, 2001, Berkaca dicermin Retak : Refleksi Konservasi dan Implikasi Bagi Pengelolaan Taman Nasional, The Gibon Foundation, Jakarta. 
Vol. 5, No. 2 : 406 - 419

http://ojs.unud.ac.id/index.php/jmhu

\section{Peraturan Perundang-undangan}

Undang-Undang Republik Indonesia

Nomor 5 Tahun 1990 tentang

Konservasi Sumber Daya Alam

Hayati dan Ekosistemnya.

Peraturan Menteri Kehutanan

Republik Indonesia Nomor :

P.53/Menhut-II/2006 tentang

Lembaga Konservasi.

Peraturan Pemerintah Nomor 8 Tahun

1999 tentang Pemanfaatan Jenis

Tumbuhan dan Satwa Liar 